\title{
Comparison of the Silica Fume Content for High-Strength Concrete Production: Chemical Analysis of the Pozzolanic Reaction and Physical Behavior by Particle Packing
}

\author{
H.F. Campos ${ }^{a *}$ (D), N.S. Klein ${ }^{a}$ (D), J. Marques Filho ${ }^{a}$ (D) \\ ${ }^{a}$ Universidade Federal do Paraná, Departamento de Construção Civil, ACF Centro Politécnico, Jardim \\ das Américas, Bloco III, 81531-980, Curitiba, PR, Brasil
}

Received: June 28, 2020; Revised: August 11, 2020; Accepted: September 19, 2020

\begin{abstract}
Silica fume (SF) is the most commonly mineral admixture used for the production of high-strength concrete (HSC) due to its chemical characteristics of pozzolanic reactivity and physical filling effect. The objective of the present work is to compare the SF content by the chemical analysis of the pozzolanic reaction and the physical behavior by particle packing techniques. The first step of the study was to analyze the SF content to consume the calcium hydroxide $(\mathrm{CH})$ produced during the hydration of Portland cement (PC), based on stoichiometric calculations. Then, the SF content for maximum packing density was obtained using analytical particle packing models and experimental tests. The compressive strength of the pastes was also measured. The results showed that the theoretical SF content for consuming $\mathrm{CH}$ is $15.6 \%$, replacing PC. According to the packing density analytical models, the ideal SF content is $15 \%$ of the total fine materials. However, the experimental results indicated the use of a smaller SF content $(10 \%)$. This difference between theoretical and experimental results is probably due to the high specific surface of the SF, which results in important surface forces between the grains, particle agglomeration and difficulty in SF densification with water.
\end{abstract}

Keywords: Silica fume, packing density, pozzolanic reaction, high-strength concrete.

\section{Introduction}

Silica fume (SF) has been routinely used as a mineral admixture to produce high-strength concrete (HSC) since the $1950 \mathrm{~s}^{1,2}$. This mineral admixture is an ultrafine powder collected from the production of silicon and ferrosilicon alloy. The silicon dioxide $\left(\mathrm{SiO}_{2}\right)$ that is released in the production process of these alloys undergoes oxidation and condenses in the form of extremely fine spherical particles of amorphous silica ${ }^{3}$. It is known that SF significantly improves the solids concentration, the mechanical properties and the durability of cementitious materials due to their physical and chemical characteristics, which provide high reactivity with the hydration products of Portland cement $(\mathrm{PC})^{1,4,5}$. The chemical reaction occurs due to its pozzolanic reactivity, i.e. the reaction of $\mathrm{SF}$ with calcium hydroxide $(\mathrm{CH})$ generated in the hydration of PC. The physical effect occurs by filling the spaces between the larger particles due to the fine and spherical particles of the SF.

From a chemical point of view, SF is mainly composed of $\mathrm{SiO}_{2}$, whose content varies depending on the type of alloy produced. The higher the silicon content of the alloy, the higher the $\mathrm{SiO}_{2}$ content of the $\mathrm{SF}^{4}$. The Brazilian standard NBR $13956-1^{6}$ specifies a minimum of $85 \%$ of $\mathrm{SiO}_{2}$ in $\mathrm{SF}$ for use with PC in concrete, mortars and pastes. The chemical effect of SF is associated with the ability to react with the $\mathrm{CH}$ formed during the hydration of the $\mathrm{PC}$, to form secondary calcium silicate hydrate (C-S-H), which is the main product responsible for the compressive strength of the hydrated

*e-mail: heloisacampos@ufpr.br cement paste ${ }^{3,7,8}$. In general, $\mathrm{CH}$ constitutes about 20 to $25 \%$ of the volume of hydration products and its crystals grow in solution. Due to their hexagonal plate morphology, $\mathrm{CH}$ crystals are relatively weak and brittle. Cracks can easily spread through regions filled with $\mathrm{CH}$ crystals, especially at the paste/aggregate interfacial transition zone (ITZ). Therefore, the consumption of $\mathrm{CH}$ present in this interface by the pozzolanic reaction is especially important to increase the compressive strength, since the ITZ becomes stronger by the formation of the secondary C-S-H. The percentage of $\mathrm{CH}$ consumed by the $\mathrm{SF}$ is represented as an index of the pozzolanic activity of $\mathrm{SF}^{7}$.

From a physical point of view, SF particles are spherical, with diameters ranging from $0.1 \mu \mathrm{m}$ to $1 \mu \mathrm{m}$ or $2 \mu \mathrm{m}$, so that the average sphere of SF is 100 times smaller than the average of $\mathrm{PC}$ particles ${ }^{4,8,9}$. Typical values for the specific area of SF are in the range of $15 \mathrm{~m}^{2} / \mathrm{g}$ to $25 \mathrm{~m}^{2} / \mathrm{g}^{3,4}$. These physical characteristics of SF result in benefits to the microstructure and mechanical properties of the concrete, since the fine particles of SF are introduced between the PC grains, reducing the space available for water and acting as a nucleation point, which makes it difficult for the $\mathrm{CH}$ crystals to be preferably formed in the $\mathrm{ITZ}^{3}$. Therefore, the resulting solid matrix that includes SF is dense even before any chemical bonds between the $\mathrm{PC}$ particles have developed ${ }^{4}$. With a high packing density in the mixture, cement and other particles are close to each other, reducing the space that needs to be filled by hydration products ${ }^{10}$. The smaller these spaces, the faster the cement hydrates fill in the gaps between cement particles, the stronger the links created by these hydrates, and most importantly, the 
stronger the concrete ${ }^{11}$. The particle packing optimization provides a guided replacement of fine materials to primarily control matrix fracture properties ${ }^{12}$, making the available particle packing technics very helpful in determining the SF content in mixes. Campos et al. ${ }^{13}$ recently demonstrated that the use of particle packing models is an efficient tool to define the matrix composition in HSC.

The particle packing technics have greater sensitivity when applied to finer materials, such as SF, since the forces between the particles that cause the agglomeration (van der Waals forces) are higher ${ }^{14}$. For small particles, the surface area in relation to their volume is higher, what makes the forces of attraction dominant in comparison with gravity. The critical size for agglomeration to occur is approximately $100 \mu \mathrm{m}^{14}$. As a result, agglomeration can cause a low degree of hydration, since water can become trapped between fine particles and, therefore, not being able to percolate and hydrate all cement particles ${ }^{15}$. In this way, the fine particles of SF will also influence the properties of fresh concrete, as it does in the hardened state.

The addition of a binder material finer than PC exerts its effects on the workability of the mixes through two major phenomena. The first phenomenon is packing density improvement, which decreases the amount of water needed for filling voids and increases the amount of excess water for forming water films to lubricate the solid particles ${ }^{16,17}$. The fine particles fill the voids and release the water; consequently, improving workability ${ }^{18}$. The other phenomenon is the surface area increment, which thins down the water films coating the solid particles and decreases the water film thickness ${ }^{17}$. For the same amount of water, with a larger surface area, the thickness of the water film will be thinner and the flow capacity will be less and vice versa ${ }^{16}$. In addition, clusters of fine particles act as larger particles, which modifies the particle size distribution and hinders the mobility of flow lines, since clusters move more slowly and act as blocks to smaller particles, increasing viscosity and generating voids ${ }^{19}$. Since it is the net effect of these two phenomena that governs the workability, the effects of SF on workability are dependent on which of the phenomena prevails: the effect of packing density improvement or the effect of surface area increment. This explains why small SF contents may improve the workability of the mixes, while higher amounts impair it. Also, in the case of mixtures without superplasticizers, the fine particles can agglomerate and not fill spaces left between larger particles, requiring even more water ${ }^{18}$.

The contents of SF in the HSC are, normally, between 5 to $15 \%$ by PC weight ${ }^{1,9,20-22}$. Values above lead to considerable increases in the final cost of the concrete, while a lower compressive strength gain. Also, when added in levels above $15 \%$, SF can increase the water consumption necessary to maintain the same level of consistency, since the volume of water released by the filler effect is not sufficient to involve the fine particles, whose specific surface area is high $^{23}$. In terms of efficiency, the consumption of PC per $\mathrm{MPa}$ of compressive strength, $16 \%$ of SF in relation to the total of fine materials, appears to be ideal for $\mathrm{HSC}^{24}$. Chen et al. ${ }^{17}$ demonstrated that considering the concurrent flowability-strength-durability performance, the ideal SF content varies from $10 \%$ to $15 \%$.
The properties of a cement-based material in the hardened state will be influenced by both the packing density of the particles and the development of the chemical reactions of $\mathrm{PC}$ and mineral admixtures. In the early ages, the influence of the packing density is the main one, while in more advanced ages, both the packing density and the degree of hydration influence the voids index. Thus, both physical and chemical behviours of SF should be considered in order to determine the composition of the pastes and concretes. In this context, the objective of the present work is to analyze both chemical and physical contributions of the SF for the production of pastes. The chemical analysis of the pozzolanic reaction was performed considering the SF content necessary to consume the $\mathrm{CH}$ produced in the hydration of the PC, based on stoichiometric calculations. On the other hand, the physical behavior of the SF was considered through particle packing techniques; i.e. the SF content for maximum packing density was obtained using analytical particle packing models and also experimentally, by the wet packing method. The compressive strength of the pastes produced for the wet packing test was also measured.

\section{Materials and Methods}

\subsection{Materials}

Pastes were produced using PC, SF and also stone powder (SP), as an inert mineral admixture. The PC used was the Brazilian cement type CP V-ARI, whose characteristics are described by the standard NBR $16697^{25}$. The SF used meets the requirements of NBR $13956-1^{6}$ and has a pozzolanic activity of $1,542 \mathrm{mg} \mathrm{CH} / \mathrm{g}$ of $\mathrm{SF}^{26}$. The $\mathrm{SP}$ used is a waste material from the production process of limestone sand. It was obtained from the quarry and then dried in a laboratory oven under a temperature of $60{ }^{\circ} \mathrm{C}$. It is classified as inert, according to NBR $5751^{27}$, which determines the pozzolanic activity with lime, and NBR $5752^{28}$, which determines the performance index with the PC. Table 1 presents the chemical composition and the physical characteristics of the three materials. The chemical composition was obtained in the $\mathrm{X}$-ray fluorescence test (XRF). The XRF used was from Panalytical, model Axios Max with Rhodium tube $4 \mathrm{kV}$. The specific gravity of the SP was determined according to the standard NBR $16605^{29}$. The specific gravities of SF and PC were obtained from the respective manufacturers. The other physical characteristics of the PC and SP were obtained by laser diffraction test (equipment Malvern 2000) performed after 1 minute of ultrasound. For SF, the equipment available to carry out the study did not allow the obtainment of diameters close to the values suggested in the literature ${ }^{4,8,9}$ and provided by the manufacturer due to the excessive agglomeration detected in the material caused by its fineness. The higher the specific surface area of the grains, the lower the gravitational forces and, consequently, the forces of attraction will be dominant. For this reason, the D50 provided by the manufacturer was used, as shown in Table 1.

The particle size distributions of PC and SP are continuous and similar to each other (Figure 1). The chemical admixture used consists of a third-generation superplasticizer with a density of $1,100 \mathrm{~kg} / \mathrm{m}^{3}$ and a solid content of $46.68 \%$, according to the manufacturer. 
Table 1. Chemical composition and physical characteristics of fine materials.

\begin{tabular}{|c|c|c|c|}
\hline \multicolumn{4}{|c|}{ Chemical composition obtained in the $\mathrm{X}$-ray fluorescence test } \\
\hline Parameter analyzed & PC & SF & SP \\
\hline $\mathrm{Al}_{2} \mathrm{O}_{3}$ & $4.10 \%$ & $0.20 \%$ & $3.00 \%$ \\
\hline $\mathrm{SiO}_{2}$ & $18.67 \%$ & $95.70 \%$ & $6.10 \%$ \\
\hline $\mathrm{Fe}_{2} \mathrm{O}_{3}$ & $2.84 \%$ & $0.10 \%$ & $1.30 \%$ \\
\hline $\mathrm{CaO}$ & $60.65 \%$ & $0.40 \%$ & $48.60 \%$ \\
\hline $\mathrm{MgO}$ & $4.07 \%$ & $0.50 \%$ & $1.20 \%$ \\
\hline $\mathrm{SO}_{3}$ & $3.04 \%$ & $0.10 \%$ & $0.20 \%$ \\
\hline Free calcium oxide $\left(\mathrm{CaO}_{\text {free }}\right)$ & $0.58 \%$ & - & - \\
\hline Insoluble residue & $0.66 \%$ & - & - \\
\hline Alkaline equivalent & $0.71 \%$ & - & - \\
\hline $\mathrm{K}_{2} \mathrm{O}$ & - & $0.70 \%$ & $0.60 \%$ \\
\hline $\mathrm{SrO}$ & - & - & $0.20 \%$ \\
\hline $\mathrm{Na}_{2} \mathrm{O}$ & - & $0.20 \%$ & $0.10 \%$ \\
\hline $\mathrm{TiO}_{2}$ & - & - & $0.10 \%$ \\
\hline $\mathrm{P}_{2} \mathrm{O}_{5}$ & - & $0.10 \%$ & $0.10 \%$ \\
\hline $\mathrm{Cl}$ & & $0.10 \%$ & - \\
\hline $\mathrm{MnO}$ & - & - & $<0.10 \%$ \\
\hline Loss on ignition & $3.25 \%$ & $1.99 \%$ & $38.44 \%$ \\
\hline \multicolumn{4}{|c|}{ Physical characteristics } \\
\hline Characteristics & PC* & $\mathbf{S F}^{* *}$ & SP* \\
\hline Specific gravity $\left(\mathrm{g} / \mathrm{cm}^{3}\right)\left(\mathrm{NBR} 16605^{29}\right)$ & 3.09 & 2.22 & 2.67 \\
\hline Specific surface $\left(\mathrm{m}^{2} / \mathrm{g}\right)$ & 1.36 & 19.00 & 1.50 \\
\hline $\mathrm{D}_{10}(\mu \mathrm{m})$ & 2.113 & - & 1.533 \\
\hline $\mathrm{D}_{50}(\mu \mathrm{m})$ & 12.046 & 0.200 & 10.649 \\
\hline $\mathrm{D}_{90}(\mu \mathrm{m})$ & 31.077 & - & 34.613 \\
\hline
\end{tabular}

*The specific surface, $\mathrm{D}_{10}, \mathrm{D}_{50}$ and $\mathrm{D}_{90}$ of PC and SP were obtained in the laser diffraction test; **The specific surface, $\mathrm{D}_{10}, \mathrm{D}_{50}$ and $\mathrm{D}_{90}$ of $\mathrm{SF}$ were obtained from the manufacturer

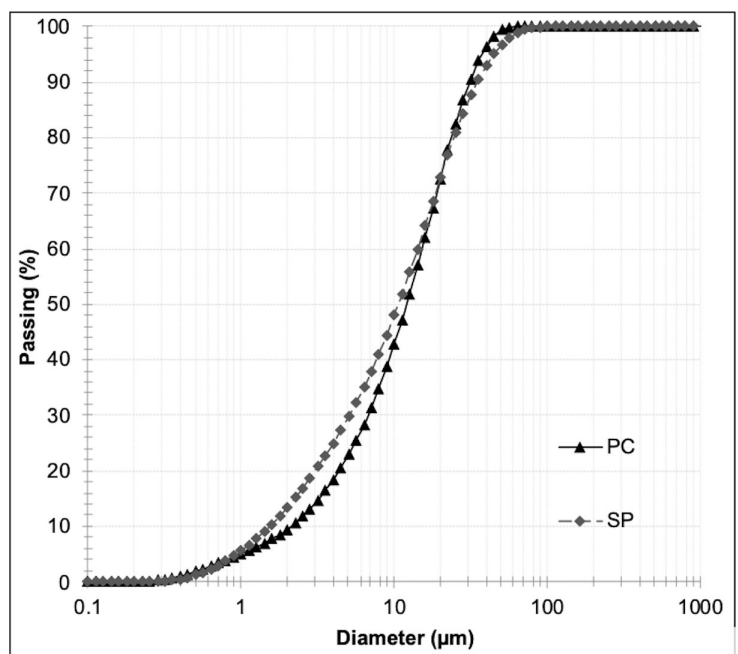

Figure 1. Particle size distribution of PC and SP.

\subsection{Methods}

The first step was to determine the SF content necessary to consume the $\mathrm{CH}$ produced by the hydration of the PC. Then, the saturation dosage test of the chemical admixture was performed experimentally. After that, the experimental packing density of each fine material was determined, individually, and these values were used as input in the analytical models for predicting the packing density of the granular set. The results obtained by the packing models were verified experimentally and the compressive strength of the produced pastes was also determined. Each step will be detailed below.

\subsubsection{SF content necessary to consume the $\mathrm{CH}$}

The determination of the SF content necessary to consume the $\mathrm{CH}$ produced during the hydration of the $\mathrm{PC}$ was performed through stoichiometric calculations. First, the potential composition of each PC compound was estimated through its chemical composition (Table 1) and the Bogue's equations, presented in Equations 1 to $4^{8}$.

$\mathrm{C}_{3} \mathrm{~S}=4.0710 \mathrm{CaO}-7.6024 \mathrm{SiO}_{2}-1.4297 \mathrm{Fe}_{2} \mathrm{O}_{3}-6.7187 \mathrm{Al}_{2} \mathrm{O}_{3}$

$\mathrm{C}_{2} \mathrm{~S}=8.6024 \mathrm{SiO}_{2}+1.0785 \mathrm{Fe}_{2} \mathrm{O}_{3}+5.0683 \mathrm{Al}_{2} \mathrm{O}_{3}-3.0710 \mathrm{CaO}$

$\mathrm{C}_{3} \mathrm{~A}=2.6504 \mathrm{Al}_{2} \mathrm{O}_{3}-1.6920 \mathrm{Fe}_{2} \mathrm{O}_{3}$

$\mathrm{C}_{4} \mathrm{AF}=3.0432 \mathrm{Fe}_{2} \mathrm{O}_{3}$

The calcium oxide $(\mathrm{CaO})$, in addition to be present in PC compounds, is also found in gypsum, limestone filler and free lime. Therefore, it is necessary to determine the $\mathrm{CaO}$ 
amount in each of these compounds before applying the Bogue's equations. The content of calcium oxide combined as gypsum $\left(\mathrm{CaO}_{\text {gypsum }}\right)$ can be obtained from the atomic mass of the elements and their chemical composition, as shown in Equation $5^{8}$.

$$
\mathrm{CaO}_{\text {gypsum }} \cdot \mathrm{SO}_{3} \cdot 2 \mathrm{H}_{2} \mathrm{O} \rightarrow \mathrm{CaSO}_{4} \cdot 2 \mathrm{H}_{2} \mathrm{O}
$$

The content of calcium oxide combined as limestone filler $\left(\mathrm{CaO}_{\text {limestone filler }}\right)$ can be obtained from the atomic mass of the elements and their chemical composition, according to Equation $6^{8}$. The carbon dioxide content is calculated considering the result obtained in the loss on ignition test, with carbon dioxide and water being the volatile compounds, so that the loss on ignition is equal to the sum of the two components, according to Equation 7.

$\mathrm{CaO}_{\text {lim estone filler }}+\mathrm{CO}_{2} \rightarrow \mathrm{CaCO}_{3}$

Loss on ignition $=\mathrm{CO}_{2}+\mathrm{H}_{2} \mathrm{O}$

Then, the theoretical CH content obtained from the PC hydration was calculated from Equations 8 and $9^{8}$, assuming the complete hydration of the PC.

$$
\begin{aligned}
& 2 \mathrm{C}_{3} \mathrm{~S}+6 \mathrm{H} \rightarrow \mathrm{C}_{3} \mathrm{~S}_{2} \mathrm{H}_{3}+3 \mathrm{CH} \\
& 2 \mathrm{C}_{2} \mathrm{~S}+4 \mathrm{H} \rightarrow \mathrm{C}_{3} \mathrm{~S}_{2} \mathrm{H}_{3}+\mathrm{CH}
\end{aligned}
$$

Finally, the SF content necessary to consume the available $\mathrm{CH}$ was estimated, through Equation 10, for the purpose of evaluation and assuming the $\mathrm{Ca} / \mathrm{Si}$ ratio for $\mathrm{C}-\mathrm{S}-\mathrm{H}$ of $1.5^{7}$.

$$
2 \mathrm{~S}+3 \mathrm{CH} \rightarrow \mathrm{C}_{3} \mathrm{~S}_{2} \mathrm{H}_{3}
$$

It is important to highlight that the results obtained using this method proposed for the stoichiometric calculations are theoretical and present some limitations. For example, the assumption of $100 \%$ cement hydration will probably not happen in practice, nor the $\mathrm{Ca} / \mathrm{Si}$ ratio for $\mathrm{C}-\mathrm{S}-\mathrm{H}$ of $1.5 \mathrm{going}$ to be constant for all the gel formed. In spite of that, it represents good approximation of the values representative for the materials used.

\subsubsection{Saturation dosage test of the chemical admixture}

The saturation dosage test of the chemical admixture was carried out for each fine material. The tests performed were the Kantro's miniature slump test ${ }^{30}$ and the Marsh's cone $^{31}$. The water/fines (w/f) ratio and the amount of solid material were kept constant, varying only the chemical admixture content according to previous tests ${ }^{32}$. For the PC and the SP, the w/f ratio was set at 0.3 and kept constant, because preliminary tests with the w/f ratio varying from 0.2 to 0.5 showed that the 0.3 content presented pastes with adequate consistency for the tests. The chemical admixture contents varied from $0.3 \%$ to $1.5 \%$. On the other hand, for the SF it was not possible to maintain the same $\mathrm{w} / \mathrm{f}$ ratio and the chemical admixture contents used for PC and SP. Further explanations regarding the tests performed with SF will be presented in item 3.2, as they are due to the results obtained. It is important to highlight that the amount of water in the chemical admixture was corrected from the total water in all the pastes.

\subsubsection{Packing density of the fine materials}

With the saturation dosage test of the chemical admixture defined, the packing density of each material was determined experimentally. The tests were performed according to the wet packing method ${ }^{33}$, which consists of dosing the materials with varying $\mathrm{w} / \mathrm{f}$ ratio and determining the voids index and the solids concentration of each mixture by measuring the apparent density of the mix. This is performed to determine the mass of a known volume of paste, which is commonly conducted using a container of known volume. With the maximum apparent density value, it is possible to obtain the solid volume of the cementitious materials $\left(\mathrm{V}_{\mathrm{c}}\right)$ and the volume of water $\left(\mathrm{V}_{\mathrm{w}}\right)$, through Equations 11 and 12, respectively.

$$
\begin{aligned}
& \mathrm{V}_{\mathrm{c}}=\frac{\mathrm{M}}{\rho_{\mathrm{w}} \mathrm{u}_{\mathrm{w}}+\sum_{\mathrm{i}=1}^{\mathrm{n}} \rho_{\mathrm{i}} \mathrm{R}_{\mathrm{i}}} \\
& \mathrm{V}_{\mathrm{w}}=\mathrm{u}_{\mathrm{w}} \times \mathrm{V}_{\mathrm{c}}
\end{aligned}
$$

in which $\mathrm{M}$ is the mass of paste filling the container used for the test, $\rho_{w}$ is the density of water, $u_{w}$ is the $w / f$ ratio, by volume, $\rho_{\mathrm{i}}$ is the specific gravity of the material $i, R_{i}$ is the volumetric ratio of the material $i$.

With the $\mathrm{V}_{\mathrm{c}}$ and $\mathrm{V}_{\mathrm{w}}$ values obtained, the voids ratio $(\mathrm{u})$, the air ratio $\left(\mathrm{u}_{\mathrm{a}}\right)$ and the solids concentration $(\Phi)$ may be determined by Equations 13 to $15^{33}$.

$$
\begin{aligned}
& \mathrm{u}=\frac{\left(\mathrm{V}-\mathrm{V}_{\mathrm{c}}\right)}{\mathrm{V}_{\mathrm{c}}} \\
& \mathrm{u}_{\mathrm{a}}=\frac{\left(\mathrm{V}-\mathrm{V}_{\mathrm{c}}-\mathrm{V}_{\mathrm{w}}\right)}{\mathrm{V}_{\mathrm{c}}} \\
& \Phi=\frac{\mathrm{V}_{\mathrm{c}}}{\mathrm{V}}
\end{aligned}
$$

For the present study, pastes were composed of the fine material (one at a time), water and the polycarboxylate-based superplasticizer admixture. The superplasticizer content was maintained according to the results obtained for the saturation dosage test (item 2.2.2). Table 2 presents the procedure for mixing the materials for the production of pastes.

The density of the pastes was determined in a $400 \mathrm{ml}$ cylindrical mold, which was filled in two layers, each layer being compacted with 30 drops applied to the flow table, in order to standardize the compaction force. With the measured densities, the solids concentrations (Equation 15), the voids ratio (Equation 13) and the air ratio (Equation 14) were obtained.

\subsubsection{SF content to achieve the maximum packing density of the granular set}

The particle packing models used to study the SF content in substitution for PC were the Compressible Packing Model $(\mathrm{CPM})^{34}$ and the Compaction-Interaction Packing Model $(\mathrm{CIPM})^{18,35}$. The $\mathrm{CPM}^{34}$ defines the packing density of granular assemblies from the particle size distribution and allows the consideration of the type of compaction applied. Aspects such as grain morphology, the presence of water and admixtures in an indirect manner were considered, since the packing density of each size class must be determined 
Table 2. Procedure for mixing the pastes, adapted from (Wong e Kwan, 2008).

\begin{tabular}{clcc}
\hline Mixing step & \multicolumn{1}{c}{ Materials } & Mixing time & Velocity \\
\hline $1^{\text {a }}$ & $50 \%$ Solid $+80 \%$ Water $+80 \%$ Superplasticizer & 3 min. & Low \\
\hline $2^{\text {a }}$ & $12.5 \%$ Solids $+5 \%$ Water $+5 \%$ Superplasticizer & 2 min. & Low \\
\hline $3^{\text {a }}$ & $12.5 \%$ Solids $+5 \%$ Water $+5 \%$ Superplasticizer & 2 min. & Low \\
\hline $4^{\text {a }}$ & $12.5 \%$ Solids $+5 \%$ Water $+5 \%$ Superplasticizer & 2 min. & Low \\
\hline $5^{\text {a }}$ & $12.5 \%$ Solids $+5 \%$ Water $+5 \%$ Superplasticizer & 2 min. & Low \\
\hline
\end{tabular}

experimentally. The $\mathrm{CPM}^{34}$ considers calculating the virtual packing density of the granular set considering each size class $i$ as dominant $\left(\gamma_{\mathrm{i}}\right)$ using Equations 16 to 18. These equations are based on three parameters: the particle size of each grain size class $\left(\mathrm{d}_{\mathrm{i}}\right)$; the packing density of each grain size class $\left(\beta_{\mathrm{i}}\right)$; and the mutual volume of each grain size class $\left(\mathrm{y}_{\mathrm{i}}\right)$.

$$
\gamma_{i}=\frac{\beta_{i}}{1-\sum_{j=1}^{i-1}\left[1-\beta_{i}+b_{i j} \times \beta_{i}\left(1-\frac{1}{\beta_{j}}\right)\right] \times y_{j}-\sum_{j=i+1}^{n}\left[1-a_{i j} \times \frac{\beta_{i}}{\beta_{j}}\right] \times y_{j}}
$$

$a_{i j}=\sqrt{1-\left(1-\frac{d_{j}}{d_{i}}\right)^{1,02}}$

$b_{i j}=1-\left(1-\frac{d_{i}}{d_{j}}\right)^{1,50}$

Finally, the compaction method used for placing the mix is considered in order to calculate its actual packing density $(\Phi)$. This is performed using the compaction index $(\mathrm{K})$, as given by Equation 19. The values of $\mathrm{K}$ corresponding to the most commonly used compaction methods in processing mixes are given in the model $^{34}$.

$$
\mathrm{K}=\sum_{\mathrm{i}=1}^{\mathrm{n}} \frac{\frac{\mathrm{y}_{\mathrm{i}}}{\beta_{\mathrm{i}}}}{\frac{1}{\Phi}+\frac{1}{\gamma_{\mathrm{i}}}}
$$

In addition to the parameters considered in the $\mathrm{CPM}^{34}$, the CIPM $^{18,35}$ considers the agglomeration of fine particles as an effect of the interaction between grains. Thus, the effects of $a_{i j}$ and $b_{i j}$ are calculated differently, as indicated in Equations 20 and 21 . The authors ${ }^{18,35}$ adopted the size of $25 \mu \mathrm{m}$ as a diameter limit for the occurrence of agglomeration between particles. This model analyzes the size of the particles from the ratio between the smallest and largest class diameters, resulting in a value between 0 and 1 . If the ratio is close to zero, the interaction between the classes is minimal and the packing density tends to be the maximum. The same equations previously presented, Equations 16 and 19, are used by the CIPM $^{18,35}$ to calculate the actual packing density of particles.

$$
\begin{aligned}
& \mathrm{a}_{\mathrm{ij}, \mathrm{c}}=\left\{\begin{array}{cc}
1-\frac{\log \left(\frac{\mathrm{d}_{\mathrm{i}}}{\mathrm{d}_{\mathrm{j}}}\right)}{\mathrm{w}_{0, \mathrm{a}}} & \log \left(\frac{\mathrm{d}_{\mathrm{i}}}{\mathrm{d}_{\mathrm{j}}}\right)<\mathrm{w}_{0, \mathrm{a}} \\
0 & \log \left(\frac{\mathrm{d}_{\mathrm{i}}}{\mathrm{d}_{\mathrm{j}}}\right) \geq \mathrm{w}_{0, \mathrm{a}}
\end{array}\right. \\
& \mathrm{w}_{0, \mathrm{a}}=\mathrm{w}_{\mathrm{a}} \cdot \mathrm{C}_{\mathrm{a}} \text { if } \mathrm{d}_{\mathrm{i}}<25 \mu \mathrm{m} \text { and } \mathrm{w}_{0, \mathrm{a}}=\mathrm{w}_{\mathrm{a}} \text { if } \mathrm{d}_{\mathrm{i}} \geq 25 \mu \mathrm{m}
\end{aligned}
$$

$$
b_{i j, c}= \begin{cases}1-\frac{\log \left(\frac{d_{j}}{d_{i}}\right)}{w_{0, b}} & \log \left(\frac{d_{j}}{d_{i}}\right)<w_{0, b} \\ 0 & \log \left(\frac{d_{j}}{d_{i}}\right) \geq w_{0, b}\end{cases}
$$

$$
\mathrm{w}_{0, \mathrm{~b}}=\mathrm{w}_{\mathrm{b}} \cdot \mathrm{C}_{\mathrm{b}} \text { if } \mathrm{d}_{\mathrm{i}}<25 \mu \mathrm{m} \text { and } \mathrm{w}_{0, \mathrm{~b}}=\mathrm{w}_{\mathrm{b}} \text { if } \mathrm{d}_{\mathrm{i}} \geq 25 \mu \mathrm{m}
$$

The SF content considered for calculations using the $\mathrm{CPM}^{34}$ and the $\mathrm{CIPM}^{18,35}$ varied from 0 to $16 \%$ and was increased in $2 \%$ intervals replacing PC by weight. This interval was chosen because the literature indicates that the range of cement replacement by the SF is between 5 and $15 \% 0^{1,9,20-22}$. The variation of intervals was $1 \%$ when approximating the highest packing density. The SP content was kept constant at $12 \%$ of the total fines. The literature indicates that the $12 \%$ content is ideal in terms of mechanical properties and efficiency (cement consumption/ $\mathrm{MPa}$ ) for conventional concrete, HSC and self-compacting concrete ${ }^{36-38}$. The K value used for calculation by the analytical models was 12 , as proposed by Fennis ${ }^{18}$.

After analyzing the results obtained using the analytical models $\left(\mathrm{CPM}^{34}\right.$ and $\left.\mathrm{CIPM}^{18,35}\right)$ the combination of materials with the highest packing density was chosen for experimental evaluation. A ternary paste was produced and tested using the wet packing method ${ }^{33}$, as previously stated. Apart from the combination that resulted in the highest packing density based on the analytical models, other proportions were also experimentally analyzed (see Table 3 ). A choice was made to verify whether the behavior of the experimental results would follow the same trend observed in the analytical models' results. The ideal water content was defined for each composition corresponding to the $\mathrm{w} / \mathrm{f}$ ratio required to reach the maximum solids concentration. This is the minimum water amount required for the mixture to form a homogeneous paste. More detailed explanations regarding the proportions and ideal $\mathrm{w} / \mathrm{f}$ ratios chosen for the experimental analysis are provided in Section 3.4, since they were defined based on the results obtained from the analytical models.

With the defined mixtures, the experimental packing density of each paste was analyzed and compared with the packing densities obtained in the analytical models $\left(\mathrm{CPM}^{34}\right.$ and $\left.\mathrm{CIPM}^{18,35}\right)$.

The compressive strength test was also performed for pastes produced at the ages of 28 and 91 days, according to NBR $5739^{39}$ using universal testing machine equipment (EMIC) with a capacity of 100 tons. The pastes were produced 
Table 3. Mixtures chosen for the experimental analysis.

\begin{tabular}{cccccc}
\hline Paste & \% PC & \% SF & \% SP & w/f \\
\hline SA10 & 78 & 10 & & & 0.16 \\
\hline SA13 & 75 & 13 & \multirow{2}{*}{12} & 0.17 \\
\hline SA15 & 73 & 15 & & 0.18 \\
\hline SA16 & 72 & 16 & & & 0.18 \\
\hline
\end{tabular}

with the same material proportions used for the packing density analysis, as indicated in Table 3. After mixing, six specimens/pastes were produced. The slurry was then placed in $(50 \times 100) \mathrm{mm}$ cylindrical molds filled in two layers, with each layer being compacted with 30 drops applied to the flow table. The molds were then covered with a plastic film to prevent water loss and were kept at laboratory temperature for 24 hours. Thereafter, the molds were removed and the specimens were cured under humidity higher than $95 \%$ and temperatures of $(23 \pm 2){ }^{\circ} \mathrm{C}$ until the date of the test.

\section{Results and Discussion}

\subsection{SF content necessary to consume the $\mathrm{CH}$}

Considering the $\mathrm{SO}_{3}$ content of the PC used (Table 1), its atomic mass and the atomic mass of the $\mathrm{CaO}$, it is possible to obtain the content of $\mathrm{CaO}_{\text {gypsum }}$ presented in Equation 22, from Equation 5 previously presented (item 2.2.1).

$$
\% \mathrm{CaO}_{\text {gypsum }}=\% \mathrm{SO}_{3} \times \frac{\mathrm{MCaO}}{\mathrm{MSO}_{3}}=3.04 \% \times 0.70=2.13 \%
$$

in which:

- $\% \mathrm{CaO}_{\text {gypsum }}$ : calcium oxide content from gypsum;

- $\quad \mathrm{SO}_{3}$ : sulfur trioxide content $(3.04 \%$, obtained from Table 1);

- $\quad \mathrm{MCaO}$ : atomic mass of calcium oxide $(56.08 \mathrm{~g} / \mathrm{mol})$;

- $\mathrm{MSO}_{3}$ : atomic mass of sulfur trioxide $(80.06 \mathrm{~g} / \mathrm{mol})$.

With the same reasoning it is possible to estimate the water content in the gypsum (Equation 23) and the carbon dioxide content (Equation 24), through the application of Equations 7 (item 2.2.1) and with the experimental result of loss on ignition (Table 1).

$$
\begin{aligned}
& \% \mathrm{H}_{2} \mathrm{O}=\% \mathrm{SO}_{3} \times \frac{2 \mathrm{MH}_{2} \mathrm{O}}{\mathrm{MSO}_{3}}=3.04 \% \times 0.45=1.37 \% \\
& \% \mathrm{CO}_{2}=3.25 \%-1.37 \%=1.88 \%
\end{aligned}
$$

in which:

- $\% \mathrm{H}_{2} \mathrm{O}$ : water content;

- $\quad \% \mathrm{CO}_{2}$ : carbon dioxide content;

- $\quad$ Loss on ignition: $3.25 \%$ (Table 1 );

- $\quad \mathrm{MH}_{2} \mathrm{O}$ : atomic mass of water $(18 \mathrm{~g} / \mathrm{mol})$.

Thus, through the application of Equation 6 (item 2.2.1) it is possible to obtain the $\mathrm{CaO}_{\text {limestone filler }}$ according to Equation 25.

$\% \mathrm{CaO}_{\text {limestone filler }}=\% \mathrm{CO}_{2} \times \frac{\mathrm{MCaO}}{\mathrm{MCO}_{2}}=1.88 \% \times 1.274=2.39 \%$

in which:

- $\% \mathrm{CaO}_{\text {limestone filler }}$ : calcium oxide content from limestone filler;

- $\mathrm{MCO}_{2}$ :atomic mass of carbon dioxide $(44.01 \mathrm{~g} / \mathrm{mol})$.
With the value of calcium oxide combined as gypsum (Equation 22), limestone filler (Equation 25) and free lime (Table 1), it was possible to calculate de actual calcium oxide used to form the PC compounds $\left(\mathrm{CaO}_{\text {actual }}\right)$. This methodology was used for the purpose of evaluating the potential composition of each PC compound, considering the complete hydration of the PC, what does not always happen in practice, especially when low w/c ratios are used. The $\mathrm{CaO}_{\text {actual }}$ content used to calculate the potential composition of PC by Bogue's equations $(\mathrm{CaO})$ is given by Equation 26.

$\mathrm{CaO}_{\text {actual }}=\% \mathrm{CaO}_{\text {total }}-\% \mathrm{CaO}_{\text {gypsum }}-\% \mathrm{CaO}_{\text {limestonefiller }}-\mathrm{CaO}_{\text {free }}=55.55 \%$

in which:

- $\quad \% \mathrm{CaO}_{\text {total }}:$ calcium oxide content from experimental results (Table 1).

With the corrected calcium oxide content it was possible to apply the Bogue's equations (Equations 21 to 24) and estimate the potential composition of PC (Table 4).

Then, the content of $\mathrm{CH}$ formed (Equations 27 and 28) can be predicted from the hydration of $\mathrm{C}_{3} \mathrm{~S}$ and $\mathrm{C}_{2} \mathrm{~S}$, presented in Equations 8 and 9 (item 2.2.1).

$$
\begin{aligned}
& \% \mathrm{CH}=\% \mathrm{C}_{3} \mathrm{~S} \times \frac{\mathrm{M} 3 \mathrm{CH}}{\mathrm{M}_{2} \mathrm{C}_{3} \mathrm{~S}}=52.60 \times 0.487=25.62 \% \\
& \% \mathrm{CH}=\% \mathrm{C}_{2} \mathrm{~S} \times \frac{\mathrm{M} \mathrm{CH}}{\mathrm{M} 2 \mathrm{C}_{2} \mathrm{~S}}=13.86 \times 0.215=2.98 \%
\end{aligned}
$$

In which:

- \% $\mathrm{CH}$ : calcium hydroxide content;

- M3CH: atomic mass of $3 \mathrm{CH}(222.24 \mathrm{~g} / \mathrm{mol})$;

- $\% \mathrm{C}_{3} \mathrm{~S}$ : tricalcium silicate content (Table 4);

- $\mathrm{M}_{2} \mathrm{C}_{3} \mathrm{~S}$ : atomic mass of $2 \mathrm{C}_{3} \mathrm{~S}(456.66 \mathrm{~g} / \mathrm{mol})$;

- $\% \mathrm{C}_{2} \mathrm{~S}$ : dicalcium silicate content (Table 4);

- $\mathrm{M}_{2} \mathrm{C}_{2} \mathrm{~S}$ : atomic mass of $2 \mathrm{C}_{2} \mathrm{~S}(344.5 \mathrm{~g} / \mathrm{mol})$.

Thus, the total $\mathrm{CH}$ formed is the sum of values obtained from Equations 27 and 28, equal to $28.60 \%$.

Based on Equation 10 and the atomic mass of SF and $\mathrm{CH}$, Equation 29 presents the stoichiometric relationship of SF pozzolanic reaction.

$$
\frac{\mathrm{M} 3 \mathrm{CaO} .3 \mathrm{H}_{2} \mathrm{O}}{\mathrm{M} 2 \mathrm{SiO}_{2}} \rightarrow 1.85
$$

in which:

- $\mathrm{M} 3 \mathrm{CaO} .3 \mathrm{H}_{2} \mathrm{O}$ : atomic mass of $3 \mathrm{CaO}^{2} 3 \mathrm{H}_{2} \mathrm{O}(222.24 \mathrm{~g} / \mathrm{mol})$; - $\mathrm{M}_{2} \mathrm{SiO}_{2}$ : atomic mass of $2 \mathrm{SiO}_{2}(120.16 \mathrm{~g} / \mathrm{mol})$.

The $\mathrm{CH}$ content can be obtained from the $\mathrm{C}_{3} \mathrm{~S}$ and $\mathrm{C}_{2} \mathrm{~S}$ contents (Equations 27 and 28). Thus, Equation 30 is proposed to relate the substitution content of PC by SF for the total calcium hydroxide consumption, assuming $100 \%$ reactivity of SF.

$$
\frac{\left(100-\mathrm{T}_{\mathrm{S}}\right) \times\left(\% \mathrm{C}_{3} \mathrm{~S} \times \frac{\mathrm{M} 3 \mathrm{CH}}{\mathrm{M}_{2} \mathrm{C}_{3} \mathrm{~S}}+\% \mathrm{C}_{2} \mathrm{~S} \times \frac{\mathrm{MCH}}{\mathrm{M}_{2} \mathrm{C}_{2} \mathrm{~S}}\right)}{\% \mathrm{~S} \times \mathrm{T}_{\mathrm{S}}}=1.85 \rightarrow \mathrm{T}_{\mathrm{S}}=13.9 \%
$$

in which:

- $\quad \mathrm{T}_{\mathrm{S}}$ : SF content, replacing PC by weight (\%);

- $\quad \% \mathrm{~S}$ : content of $\mathrm{SiO}_{2}$ present in $\mathrm{SF}$ (Table 1).

However, it is known that in practice not $100 \%$ SF reacts with $\mathrm{CH}$. Considering the SF used in the present study, the pozzolanic activity is $1,542 \mathrm{mg} \mathrm{CH} / \mathrm{g}$ of $\mathrm{SF}$, as previously presented (item 2.1). Thus, Equation 31 predicts the SF content, considering its reactivity. 

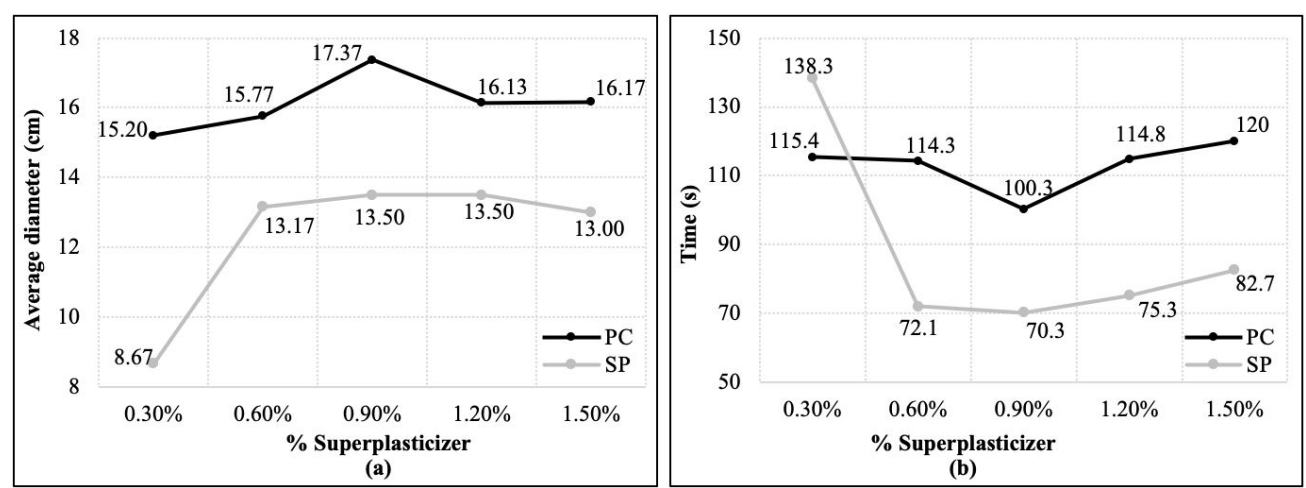

Figure 2. Saturation dosage test of the superplasticizer with PC and SF in the Kantro's Miniature Slump Test ${ }^{30}$ (a) and in the Marsh's cone ${ }^{31}$ (b).

Table 4. Potential composition of PC.

\begin{tabular}{cc}
\hline Element & Content \\
\hline $\mathrm{C}_{3} \mathrm{~S}$ & $52.60 \%$ \\
\hline $\mathrm{C}_{2} \mathrm{~S}$ & $13.86 \%$ \\
\hline $\mathrm{C}_{3} \mathrm{~A}$ & $6.06 \%$ \\
\hline $\mathrm{C}_{4} \mathrm{AF}$ & $8.64 \%$ \\
\hline
\end{tabular}

$$
\frac{\left(100-\mathrm{T}_{\mathrm{SR}}\right) \times\left(\% \mathrm{C}_{3} \mathrm{~S} \times \frac{\mathrm{M} 3 \mathrm{CH}}{\mathrm{M}_{2} \mathrm{C}_{3} \mathrm{~S}}+\% \mathrm{C}_{2} \mathrm{~S} \times \frac{\mathrm{M} \mathrm{CH}}{\mathrm{M}_{2} \mathrm{C}_{2} \mathrm{~S}}\right)}{\mathrm{T}_{\mathrm{SR}}}=1.542 \rightarrow \mathrm{T}_{\mathrm{SR}}=15.6 \%
$$

in which:

- $\quad \mathrm{T}_{\mathrm{SR}}$ : SF content, replacing PC by weight $(\%)$, considering the reactivity of the SF used.

Thus, the stoichiometric calculations showed that the SF content needed to consume $\mathrm{CH}$ is $15.6 \%$ replacing $\mathrm{PC}$ by weight. It is important to highlight the importance of maintaining $\mathrm{CH}$ in the concrete in order to have alkaline reserve and passivation of the reinforcement. Therefore, total consumption of $\mathrm{CH}$ is not recommended or ideal.

\subsection{Saturation dosage test of the chemical admixture}

The results obtained in the Kantro's miniature slump test $^{30}$ and the Marsh's cone ${ }^{31}$ are shown in Figure 2a and b, respectively.

It can be observed from Figure 2 that the average diameter increased (Figure 2a) and the time needed for the pastes to flow through the Marsh's cone decreased (Figure 2b) until the content of $0.9 \%$ of superplasticizer for the PC. Therefore, $0.9 \%$ was considered to be the saturation dosage for the PC. For the SP, it can be noted that the average diameter has increased and the time needed for the pastes to flow through the Marsh's cone have reduced significantly to the content of $0.6 \%$ of superplasticizer, being possible to measure some small benefit up to $0.9 \%$. As the PC saturation point was $0.9 \%$, it was decided to adopt this value to produce the pastes, given that the fine materials will be part of the same mixture and that the $0.9 \%$ content meets the saturation point of both PC and SP.

The saturation dosage tests were carried out with the SF with a gradual increase in the $\mathrm{w} / \mathrm{f}$ ratio from 0.4 to 1.0 and the superplasticizer content varying from $0 \%$ to $3 \%$. It was noted that even when the highest water and chemical admixture

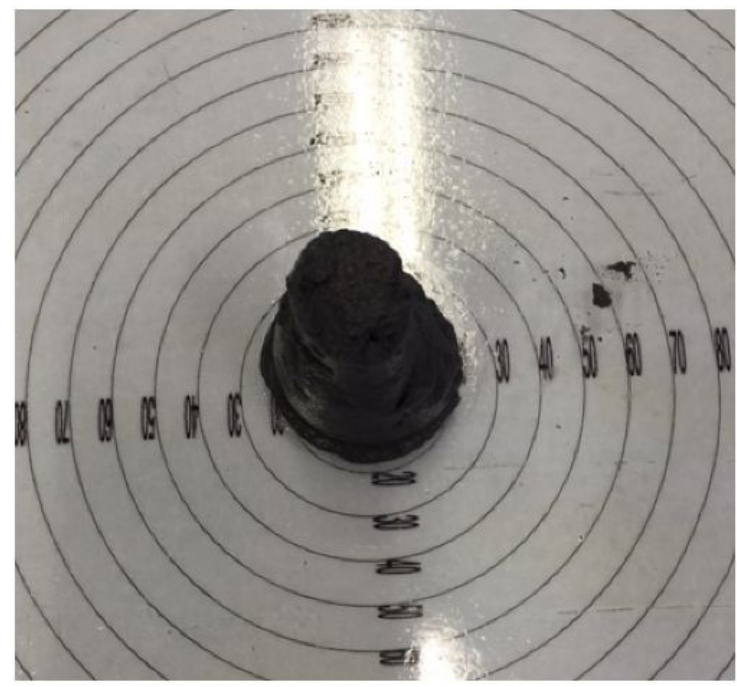

Figure 3. SF paste after the Kantros's miniature slump test ${ }^{30}$, produced with the highest $\mathrm{w} / \mathrm{f}$ ratio $(\mathrm{w} / \mathrm{f}=1.0)$ and superplasticizer content $(3 \%)$.

contents were used, it was not possible to perform the tests due to the lack of fluidity of the pastes. Figure 3 illustrates this situation, where no opening after the Kantro's miniature slump test ${ }^{30}$ was verified, the diameter of the opening remaining the measurement of the cone itself. This is due to the fineness of SF and its high specific surface, requiring a chemical admixture content higher than $3 \%$ in order for the SF pastes to flow. However, the content of the superplasticizer used should not be higher than the manufacturer's recommendation $(2 \%)$. If so, some problems could arise, such as problems with setting, costs or even acceptance of the mix from the industry. Therefore, it was decided to set the superplasticizer content at $0.9 \%$ of the total weight of fine materials for all the pastes, as it was the saturation dosage measured for the PC and SP and given that the three materials (PC, SP and $\mathrm{SF})$ will be part of the same mixture.

\subsection{Packing density of the fine materials}

Figure 4 shows the solids concentration and voids ratio for the three materials studied.

It can be observed in Figure 4 the inverse relationship between the solids concentration and the voids ratio, as 


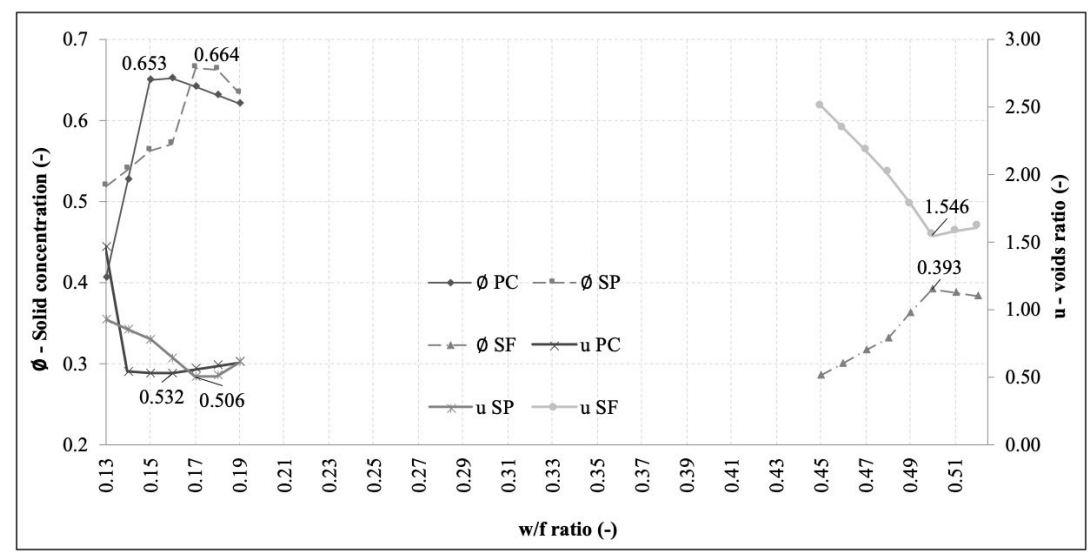

Figure 4. Solids concentration and voids ratio for PC, SP and SF.

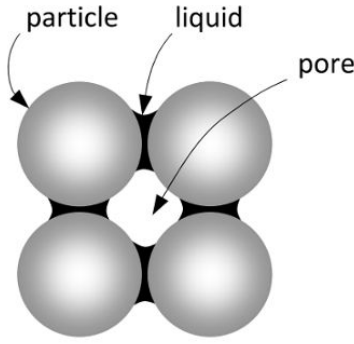

(a) pendular state

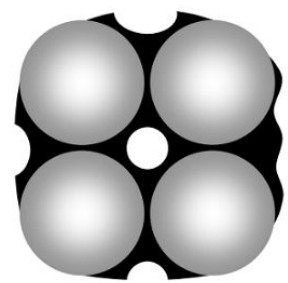

(b) funicular state

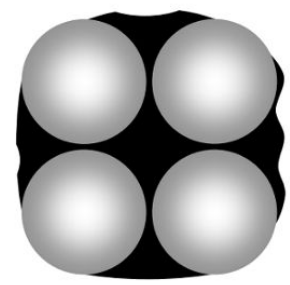

(c) saturated state

Figure 5. The states associated with agglomeration of powders due to a wetting liquid ${ }^{18}$.

expected. For the PC, the maximum solids concentration found was 0.653 , which corresponds to a $\mathrm{w} / \mathrm{f}$ ratio of 0.16 . This maximum solids concentration represents the packing density of the PC. The voids ratio achieved for this material was equal to 0.532 . Notably, Wong and $\mathrm{Kwan}^{33}$ obtained a packing density of 0.546 and 0.622 for PC without and with $3 \%$ of superplasticizer, respectively. Klein et al. ${ }^{40}$ reached the maximum packing density for the PC of 0.534 without superplasticizer, 0.561 with $0.5 \%$ superplasticizer, and 0.599 with $1 \%$ superplasticizer. Campos et al..$^{41}$ obtained a packing density of 0.610 for PC, with $0.9 \%$ of superplasticizer.

It should be noted that, for the $\mathrm{PC}$, when the w/f ratio is lower than 0.16 , the amount of water in the mixture is insufficient to wet all the component particles. This situation indicates the pendular state, with capillary bridges localized at particle contacts, as illustrated in Figure $5 \mathrm{a}^{18}$. In the pendular state, the particles are held together by liquid bridges at the contact points of the pendulum connections ${ }^{42}$. As the water content increases, the pendular bonds merge, but pores are not completely filled with liquid. This situation characterizes the funicular state, represented in Figure 5b, where the bond strength between the particles increases as a result of the higher surface energy of the liquid. In this state, there is a connected path between both the liquid phase and the pores $^{18}$. This situation represents the packing density of the mixture, as particles are in contact with each other. For w/f ratios higher than 0.16 , the remaining pores are filled with water, and excess water is observed between the particles.
As a result of the increase in the water volume, particles start to move away from each other, reducing the concentration of solids and increasing the voids ratio (Figure 5c).

The same reasoning used for the PC can be applied to SP, which exhibited a packing density of 0.664 and a voids ratio of 0.506 when the w/f ratio was 0.17 (Figure 4). Campos et al. ${ }^{13}$ obtained a packing density of 0.693 and a voids ratio of 0.442 when the $\mathrm{w} / \mathrm{f}$ ratio was 0.15 , for SP, with $0.9 \%$ of superplasticizer. When analyzing the SF results (Figure 4), a packing density of 0.393 is observed, which was the lowest among the materials studied. On the other hand, the voids ratio of 1.546 is much higher than the ones obtained for the PC and SP. Achieving a voids ratio higher than the unit indicates that in the SF mixture there are more voids than solids, probably due to the high formation of agglomerates. The SF curves also highlight the need for a larger amount of water to obtain the packing density $(\mathrm{w} / \mathrm{f}=0.50)$, in comparison with PC and SP, which can be explained by its fineness, in addition to the fact that the content of superplasticizer used is less than necessary to disperse the SF particles. Since the packing density is reached when all particles of the system are wet, the SF water demand will be higher due to its higher specific surface area. Additionally, in finer particles, the relation between surface area and volume is higher, which causes the forces of attraction between grains to be dominant, thus, favoring the formation of agglomerates where air can be entrapped and leading to a higher voids ratio ${ }^{19,23}$. For the maximum solids concentration of each individual material presented 
(Figure 4), the air ratio was calculated as previously described. Figure 6 shows the obtained results.

It can be observed in Figure 6 that even at the maximum concentration of solids, air is still present in the mixtures, due to the funicular state of the particles and the surface tension of the water ${ }^{18,42}$. It is important to highlight that for the SF the air ratio is $45.6 \%$, much higher than that for PC and for SP, due to its fineness and the surface effects leading to agglomeration. Furthermore, the superplasticizer content used was lower than the amount needed to provide fluidity of the SF paste, as already mentioned.

\subsection{SF content to achieve the maximum packing density of the granular set}

Figure 7 shows the results obtained with the application of the $\mathrm{CPM}^{34}$ and the CIPM ${ }^{18,35}$ models, with SF ranging from 0 to $16 \%$, replacing $\mathrm{PC}$, and keeping the SP content fixed at $12 \%$.

These results, presented in Figure 7, indicate that the highest packing density was achieved when SF content was $15 \%$ for both models $\left(\mathrm{CPM}^{34}\right.$ and $\left.\mathrm{CIPM}^{18,35}\right)$. These results are

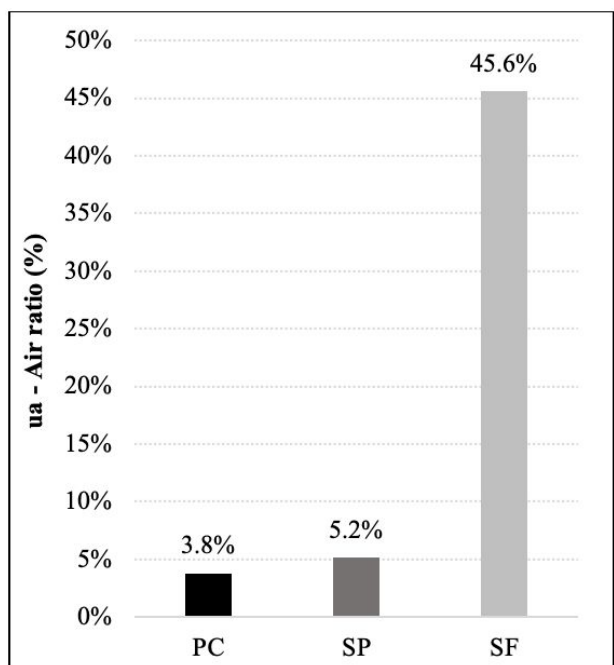

Figure 6. Air ratio (\%) at the maximum solids concentration for $\mathrm{PC}, \mathrm{SP}$ and SF. in agreement with the literature, since Chen et al. ${ }^{17}$ recently demonstrated that the ideal SF content can be around 15\%, considering the concurrent flowability-strength-durability performance. This combination of materials was chosen for the experimental analysis by the wet packing method ${ }^{33}$. Other mixtures were also chosen, as previously mentioned. The selection mixtures were made considering combinations with lower contents of SF, in order to verify if the experimental behavior followed the same trend observed in the results of the analytical models used. The combination with the highest PC replacement content $(16 \% \mathrm{SF})$ was also analyzed. Table 3, presented previously, summarizes all combinations of materials tested experimentally.

The results obtained for the solids concentration of the ternary pastes (combinations presented in Table 3 ) are shown in Figure 8, in which the maximum concentrations of solids correspond to the packing density of the granular $\operatorname{sets}^{33}$ (in the presence of water and the superplasticizer). Figure 9 compares the experimental packing densities with those obtained by using the $\mathrm{CPM}^{34}$ and $\mathrm{CIPM}^{18,35}$.

It may be observed from Figures 8 and 9 that increasing the SF content from $10 \%$ to $16 \%$ did not result in an increase in the experimental packing density. This is explained by the fineness of the SF, since the attraction forces between grains are dominant for finer particles and favor the formation of agglomerates ${ }^{23,43}$. Therefore, the packing density does not improve with the incorporation of SF in the values range tested. Among the studied mixtures, the SF10 exhibited the highest experimental packing density (0.670). Klein et al. ${ }^{40}$ obtained a packing density of 0.559 in cement paste with $12 \% \mathrm{SF}$ and $0.5 \%$ superplasticizer. Moreover, the highest packing density obtained by Campos et al. ${ }^{41}$ was 0.621 in cement paste with $18 \% \mathrm{SP}, 8 \% \mathrm{SF}$ and $0.9 \%$ superplasticizer.

It can also be observed, in Figure 9, that when the SF content increases, a reduction in the experimental packing density occurred. On the other hand, the results of the analytical models indicate that an increase in packing density can be obtained when the SF content increases up to $15 \%$. This difference, between the experimental and analytical results, is due to the high specific surface of the SF, already mentioned. On average, the $\mathrm{CPM}^{34}$ results were $4.6 \%$ higher than the experimental results. Similar values were found in the literature when the same model was used ${ }^{23,41}$. The average

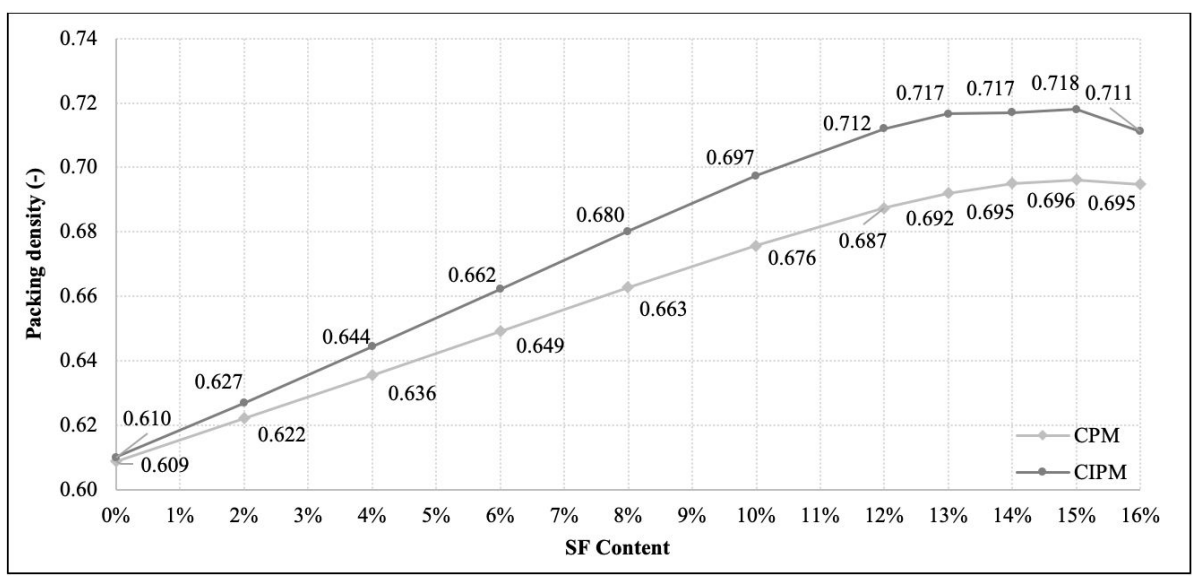

Figure 7. Packing densities of the PC, SP and SF combinations using the $\mathrm{CPM}^{34}$ and $\mathrm{CIPM}^{18,35}$ models. 
results obtained for the CIPM ${ }^{18,35}$ were $7.8 \%$ higher than the experimental results.

The literature shows that the ideal SF content defined in terms of particle packing for the production of pastes can be applied for the production of HSC. Campos et al. ${ }^{13}$ recently demonstrated that the application of particle packing models to define the SF content in the pastes resulted in HSC with adequate properties. The authors defined the SF content in the paste at $14 \%$ of the total fine materials. The results indicate that a compressive strength of $104 \mathrm{MPa}$ and a dynamic modulus of elasticity of $60 \mathrm{GPa}$ were obtained for a HSC with $336 \mathrm{~kg} / \mathrm{m}^{3}$ of cement. All studied concretes presented by the authors showed very high workability (slump $>200 \mathrm{~mm}$ ), excellent quality according to the ultrasonic pulse velocities $(>5150 \mathrm{~m} / \mathrm{s})$ and insignificant corrosion risk due to the electrical resistivity test $(>200 \mathrm{~K} \Omega \mathrm{cm})^{13}$.

Figure 10 presents the results obtained for the compressive strength of the pastes.

It can be observed, in Figure 10, that the compressive strengths decrease with the increase in the SF content at 28 days, in the same way as the experimental packing density. The pastes with higher SF contents present more voids to be filled with the cement hydration products and pozzolanic reaction. It should also be noted that by increasing the SF content in the pastes, the cement content is reduced. Therefore, the decrease in compressive strength at 28 days would also be a result of the cement hydration occurring more quickly than the pozzolanic reaction. At 91 days, the decrease in compressive strength was less pronounced, which may be the result of the pozzolanic reaction of SF, which had enough time to develop. In both ages, the highest compressive strength was obtained with a $10 \%$ SF content. Also, from the durability point of view, the use of $10 \% \mathrm{SF}$ would be interesting because it does not fully consume the $\mathrm{CH}$, maintaining the alkaline reserve of the concrete produced with these pastes composition and favoring the passivation of reinforcement in reinforced concrete. It can also be observed in Figure 9 that some dispersion values were a little high. Due to the low w/s ratios used, together with the high packing of the mixtures, molding the specimens was quite difficult.

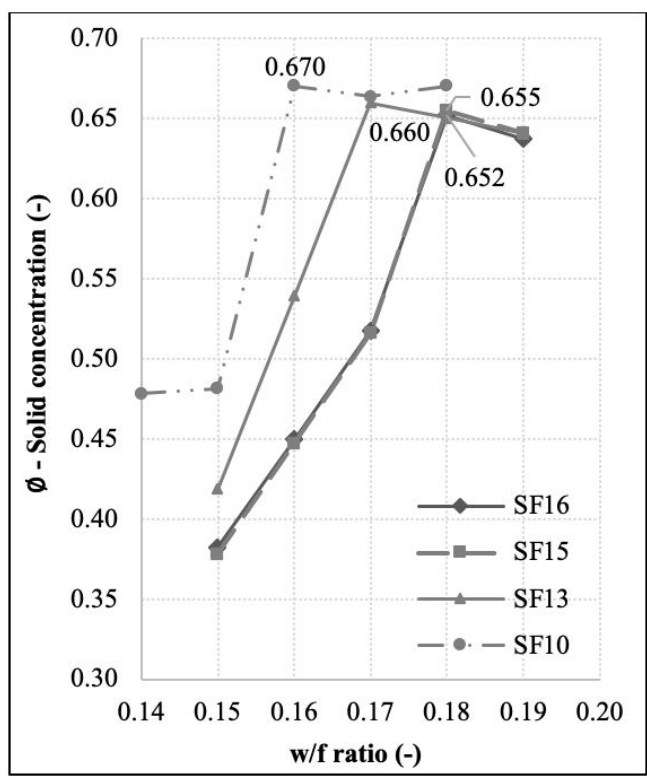

Figure 8. Solids concentration of the ternary pastes with PC, SP and SF.

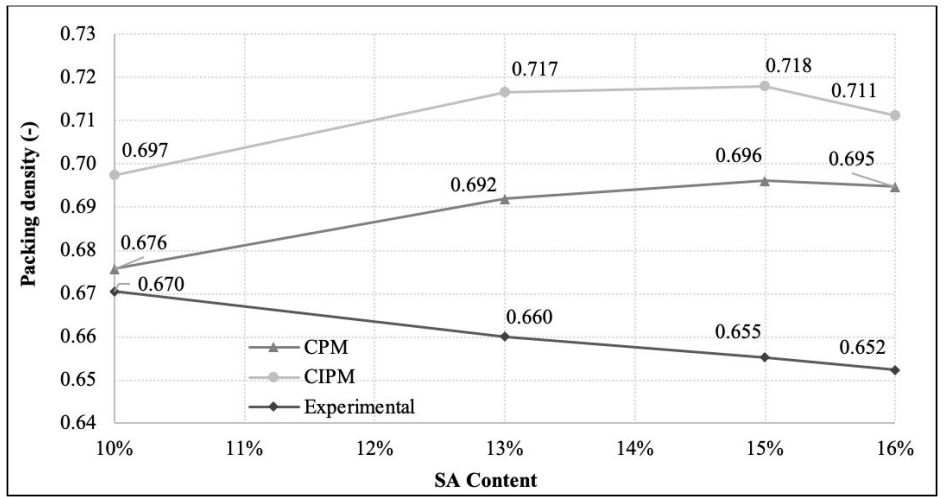

Figure 9. Packing densities of the PC, SP and SF combinations using the $\mathrm{CPM}^{34}$ and $\mathrm{CIPM}^{18,35}$ models and the experimental method ${ }^{33}$. 


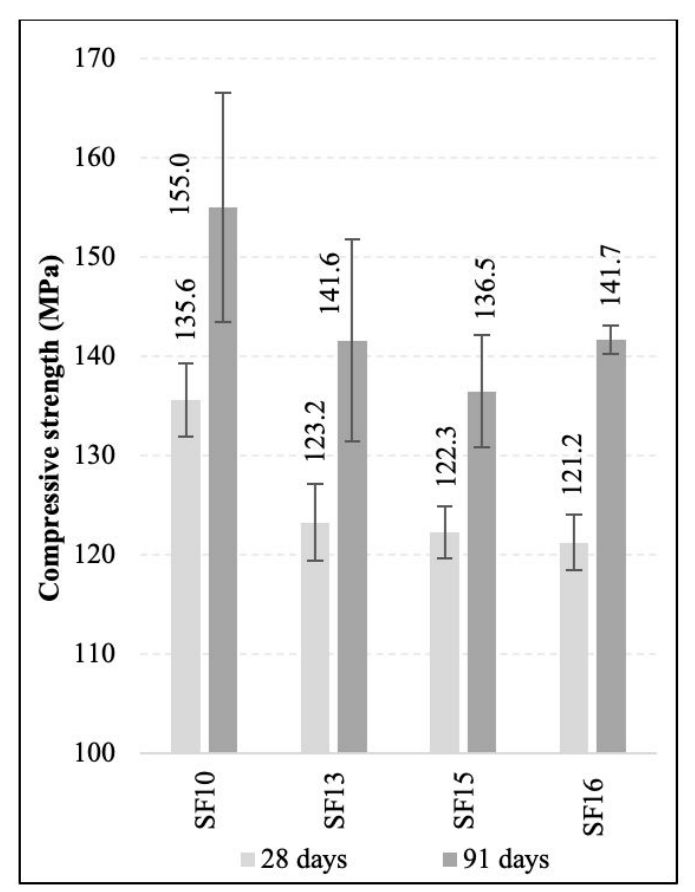

Figure 10. Compressive strength of the ternary pastes with $\mathrm{PC}$, $\mathrm{SP}$ and SF.

\section{Conclusions}

After performing the experiments and analyzing the obtained results, the following conclusions can be made:

- In terms of stoichiometric calculations, the total $\mathrm{CH}$ content produced in the hydration of the $\mathrm{PC}$ is $28.6 \%$. Considering the reactivity of SF and the chemical composition of the materials used, the theoretical $\mathrm{SF}$ content for consuming $\mathrm{CH}$ was $15.6 \%$, replacing the PC by weight.

- For the PC, the saturation dosage of the superplasticizer was $0.9 \%$, by cement weight. For the SP, it was observed that the saturation dosage was $0.6 \%$, presenting a slight increase in the spreading for the content of $0.9 \%$. Thus, it was decided to adopt the same value of $0.9 \%$ for SP, given that the fine materials will be part of the same mixture and that this content meets the saturation dosage of both (PC and SP). For the SF, it was not possible to perform the test, as a superplasticizer content higher than $3 \%$ would be necessary, which is higher than the manufacturer's recommendation, so the same value of $0.9 \%$ was adopted.

- The highest packing density of the individual materials and, consequently, the lowest voids index was of the SP, due to the fines present in its composition. The SF, on the other hand, presented the lowest packing density, a voids ratio and an air ratio much higher than the ones for $\mathrm{PC}$ and SP, due to the agglomeration of the particles and the surface effects.
- The highest packing density for the analytical models $\left(\mathrm{CPM}^{34}\right.$ and $\mathrm{CIPM}^{18,35}$ ) was for the content of $15 \%$ SF (SF15). On the other hand, experimental results showed that the mixture with the lowest SF content (SF10) presented the highest packing density. This difference was observed due to the phenomena resulting from the relatively high specific surface of the SF, since the forces of attraction between the grains are dominant for finer particles, favoring the formation of agglomerates. These interparticle forces among the fine grains were not captured by the models. On average, the results of the analytical model were $4.6 \%\left(\mathrm{CPM}^{34}\right)$ and $7.8 \%\left(\mathrm{CIPM}^{18,35}\right)$ higher than the experimental results.

- Compressive strengths decreased with an increase in SF content at 28 days, as did the experimental packing density. Pastes with higher SF content have more voids to be filled by cement hydration products and pozzolanic reaction. In addition, $\mathrm{PC}$ hydration occurs more quickly than the pozzolanic reaction. At 91 days, the decrease in compressive strength was less pronounced, which may be the result of SF pozzolanic reaction, which had more time to develop. In both ages, the highest compressive strength was obtained with a $10 \%$ SF content.

Therefore, the chemical contribution of SF for the pastes studied would be maximized with $15.6 \%$ of the mineral admixture replacing PC by weight. However, from the durability point of view, the full consumption of the $\mathrm{CH}$ is not recommended as it is important to maintain the alkaline reserve of the concretes produced with the studied pastes. This is in line with the results obtained in the particle packing studies, as the experiments showed that $10 \%$ SF would contribute for achieving the highest packing density of the granular set. Compressive strength was also higher with $10 \%$ $\mathrm{SF}$ in the mix. Using this proportion, apart from maximizing the physical behavior of the SF, would also guarantee the presence of remaining $\mathrm{CH}$ in the mixture. Future research related to the durability of concretes produced with high levels of SF is recommended, since it could reduce the alkalinity of the concretes produced.

\section{Acknowledgments}

The authors would like to thank the companies Itambé, Grace, and Concrebrás, which kindly provided all of the necessary materials. We would also like to thank the Postgraduation Program in Civil Construction Engineering at the Federal University of Paraná (PPGECC/UFPR) for the infrastructure support provided.

\section{References}

1. Mazloom M, Ramezanianpour AA, Brooks J. Effect of silica fume on mechanical properties of high-strength concrete. Cement Concr Compos. 2004;26(4):347-57. http://dx.doi.org/10.1016/ S0958-9465(03)00017-9.

2. Wang X, Hou P, Yu J, Zhou X, Cheng X. The effects of silica fume on $\mathrm{C}_{3}$ A hydration. Constr Build Mater. 2020;250:118766. http://dx.doi.org/10.1016/j.conbuildmat.2020.118766. 
3. Dal Molin DC. Adições minerais. In: Isaia GC, editor. Concreto: ciência e tecnologia. São Paulo: Ibracon; 2011. vol. 1.

4. Aïtcin P-C. Concreto de alto desempenho. 1st ed. São Paulo: PINI; 2000. $695 \mathrm{p}$

5. Tutikian BF, Isaia GC, Helene P. Concreto de alto e ultra-alto desempenho. In: Isaia GC, editor. Concreto: ciência e tecnologia. São Paulo: Ibracon; 2011. p. 1283-1325. vol. 2.

6. ABNT: Associação Brasileira de Normas Técnicas. NBR 139561: sílica ativa para uso com cimento Portland em concreto, argamassa e pasta. Parte 1: requisitos. Rio de Janeiro: ABNT, 2016.

7. Rao GA. Investigations on the performance of silica fumeincorporated cement pastes and mortars. Cement Concr Res. 2003;33(11):1765-70. http://dx.doi.org/10.1016/S00088846(03)00171-6.

8. Neville AM. Propriedades do concreto. 5. ed. Porto Alegre: Bookman; 2016. 912 p.

9. ACI Committee 363: American Concrete Institute Committee 363. ACI 363R-10: report on high-strength concrete. Farmington Hills: ACI Committee 363; 2010 .

10. Fennis SAAM, Walraven JC. Using particle packing technology for sustainable concrete mixture design. Heron. 2012;57(2):73101.

11. Bentz DP, Aitcin P-C. The hidden meaning of water-cement ratio. Concr Int. 2008;30(5):51-4.

12. Hisseine OA, Tagnit-Hamou A. Development of ecological strainhardening cementitious composites incorporating high-volume ground-glass pozzolans. Constr Build Mater. 2020;238:117740. http://dx.doi.org/10.1016/j.conbuildmat.2019.117740.

13. Campos HF, Marques Filho J, Klein NS. Proposed mix design method for sustainable high-strength concrete using particle packing optimization. J Clean Prod. 2020;265:121907. http:// dx.doi.org/10.1016/j.jclepro.2020.121907.

14. Yu AB, Feng CL, Zou RP, Yang RY. On the relationship between porosity and interparticle forces. Powder Technol. 2003;130(13):70-6. http://dx.doi.org/10.1016/S0032-5910(02)00228-0.

15. Grazia MT, Sanchez LFM, Romano RCO, Pileggi RG. Investigation of the use of continuous particle packing models (PPMs) on the fresh and hardened properties of low-cement concrete (LCC) systems. Constr Build Mater. 2019;195:524-36. http://dx.doi.org/10.1016/j.conbuildmat.2018.11.051.

16. Li LG, Kwan AKH. Concrete mix design based on water film thickness and paste film thickness. Cement Concr Compos. 2013;39:33-42. http://dx.doi.org/10.1016/j.cemconcomp.2013.03.021.

17. Chen JJ, Ng PL, Chu SH, Guan GX, Kwan AKH. Ternary blending with metakaolin and silica fume to improve packing density and performance of binder paste. Constr Build Mater. 2020;252:119031. http://dx.doi.org/10.1016/j.conbuildmat.2020.119031.

18. Fennis SAAM. Design of ecological concrete by particle packing optimization [thesis]. Holanda: Delft University of Technology; 2011.

19. Damineli BL. Conceitos para formulação de concretos com baixo consumo de ligantes: controle reológico, empacotamento e dispersão de partículas [thesis]. São Paulo: Escola Politécnica, Universidade de São Paulo; 2013.

20. Khan MI. Isoresponses for strength, permeability and porosity of high performance mortar. Build Environ. 2003;38(8):1051-6. http://dx.doi.org/10.1016/S0360-1323(01)00111-1.

21. Wong HS, Abdul Razak H. Efficiency of calcined kaolin and silica fume as cement replacement material for strength performance. Cement Concr Res. 2005;35(4):696-702. http:// dx.doi.org/10.1016/j.cemconres.2004.05.051.

22. Wongkeo W, Thongsanitgarn P, Ngamjarurojana A, Chaipanich A. Compressive strength and chloride resistance of selfcompacting concrete containing high level fly ash and silica fume. J Mater Des. 2014;64:261-9. http://dx.doi.org/10.1016/j. matdes.2014.07.042.
23. Hermann A, Langaro EA, Silva SHLDA, Klein NS. Empacotamento de partículas de cimento e sílica ativa em pastas pelo uso de modelo analítico. Rev IBRACON Estrut Mater. 2016;9(1):4865. http://dx.doi.org/10.1590/S1983-41952016000100004.

24. Campos HF, Klein NS, Marques Filho J, Bianchini M. Lowcement high-strength concrete with partial replacement of Portland cement with stone powder and silica fume designed by particle packing optimization. J Clean Prod. 2020;261:121228. http://dx.doi.org/10.1016/j.jclepro.2020.121228.

25. Associação Brasileira de Normas Técnicas. NBR 16697: cimento Portland: requisitos. Rio de Janeiro: ABNT; 2018.

26. Souza DJ. Capacidade de adições minerais em mitigar o ataque por sulfatos de sódio e magnésio em argamassas de cimento Portland [dissertation]. Curitiba: Universidade Federal do Paraná; 2016.

27. ABNT: Associação Brasileira de Normas Técnicas. NBR 5751: materiais pozolanicos: determinação da atividade pozolanica com cal aos sete dias. Rio de Janeiro: ABNT; 2015.

28. ABNT: Associação Brasileira de Normas Técnicas. NBR 5752: materiais pozolânicos: determinação do índice de desempenho com cimento Portland aos 28 dias. Rio de Janeiro: ABNT; 2014.

29. ABNT: Associação Brasileira de Normas Técnicas. NBR 16605: cimento Portland e outros materiais em pó: determinação da massa específica. Rio de Janeiro: ABNT; 2017.

30. Kantro D. Influence of water-reducing admixtures on properties of cement paste: a miniature slump test. Cem Concr Aggreg. 1980;2(2):95-102. http://dx.doi.org/10.1520/CCA10190J.

31. ABNT: Associação Brasileira de Normas Técnicas. NBR 7681: Calda de cimento para injeção. Rio de Janeiro: ABNT; 2013.

32. Campos HF. Dosagem de concreto sustentável e de alta resistência, otimizada por modelos de empacotamento de partículas, com substituição parcial do cimento Portland por pó de pedra e sílica ativa [thesis]. Curitiba: Universidade Federal do Paraná; 2019.

33. Wong HHC, Kwan AKH. Packing density of cementitious materials: part 1: measurement using a wet packing method. Mater Struct. 2008;41(4):689-701. http://dx.doi.org/10.1617/ s11527-007-9274-5.

34. De Larrard F. Concrete mixture proportioning: a scientific approach. London: E\&FN SPON; 1999. (Modern Concrete Technology Technology Series; 9).

35. Fennis SAAM, Walraven JC, Den Uij1 JA. Compaction-interaction packing mode: regarding the effect of fillers in concrete mixture design. Mater Struct Constr. 2013;46(3):463-78. http://dx.doi. org/10.1617/s11527-012-9910-6.

36. Campos HF. Concreto de alta resistência utilizando pó de pedra como substituição parcial do cimento Portland: estudo experimental [dissertation]. Curitiba: Universidade Federal do Paraná; 2015.

37. Hoffmann L. Efeitos da adição de materiais pulverulentos proveniente da britagem de rochas na resistência de concretos convencionais [dissertation]. Curitiba: Universidade Federal do Paraná; 2015.

38. Polucha A. Estudo experimental de concreto auto-adensável utilizando areia $100 \%$ artificial e fíler calcário como substituição parcial do cimento Portland [dissertation]. Curitiba: Universidade Federal do Paraná; 2016.

39. ABNT: Associação Brasileira de Normas Técnicas. NBR 5739: concreto: ensaio de compressão de corpos-de-prova cilíndricos. Rio de Janeiro: ABNT; 2007.

40. Klein NS, Cavalaro S, Aguado A, Segura I, Toralles B. The wetting water in cement-based materials: modeling and experimental validation. Constr Build Mater. 2016;121:34-43. http://dx.doi. org/10.1016/j.conbuildmat.2016.05.164.

41. Campos HF, Rocha TMS, Reus GC, Klein NS, Marques Filho J. Determination of the optimal replacement content of Portland cement by stone powder using particle packing methods and 
analysis of the influence of the excess water on the consistency of pastes. Rev IBRACON Estrut Mater. 2019;12(2):210-32. http://dx.doi.org/10.1590/s1983-41952019000200002.

42. Iveson SM, Litster JD, Hapgood K, Ennis BJ. Nucleation, growth and breakage phenomena in agitated wet granulation processes: a review. Powder Technol. 2001;117(1-2):3-39. http://dx.doi.org/10.1016/S0032-5910(01)00313-8.

43. Castro AL, Pandolfelli VC. Revisão: conceitos de dispersão e empacotamento de partículas para a produção de concretos especiais aplicados na construção civil. Ceramica. 2009;55(333):18-32. 